\title{
Fly Ash Resistivity Profiling for South African Coal Fired Power Stations
}

\author{
Gerald Chauke and Rupert Gouws \\ Faculty of Engineering, North-West University, Potchefstroom 2520, South Africa
}

Received: March 27, 2013 / Accepted: June 18, 2013 / Published: December 31, 2013.

\begin{abstract}
Particulate emission is a major problem in industrial processes, mainly power plants that make use of coal as a primary source of energy. Stringent emissions limits, set by government organisations requires industries to conform to these limits to ensure that air quality is sustained and with minimum pollutant present. Electrostatic precipitators are typically used to filter and collect these particulate emissions. Fly ash resistivity is a primary parameter in the collection of particulate emissions, and there is a resistivity range at which electrostatic precipitator collection is most efficient and anything outside this range limits, their operation. High resistivity ash results in back-corona discharge, whilst low resistivity results in particle re-entrainment into the flue gas stream. The purpose of this paper is to investigate and obtain a fly ash resistivity profile for existing power plants in South Africa. Ash samples obtained from power plants are, tested making use of an ash-resistivity test oven, in accordance with IEEE Standard 548-1984. This paper discusses obtained experimental results, to determine the resistivity profile at which South African power plant electrostatic precipitators operate. The electrical efficiency of the electrostatic precipitator system is evaluated based on the obtained resistivity profiles.
\end{abstract}

Key words: Electrostatic precipitator, fly ash, resistivity, back-corona, re-entrainment.

\section{Introduction}

Ash resistivity is a primary parameter in the effective collection of fly ash. It is dependent on a wide range of factors, such as coal quality and the combustions process. These factors determine the chemical composition of the produced ash.

ESP's have been design to operate at an optimum resistivity of at $1 \times 10^{8}$ to $1 \times 10^{11} \Omega \cdot \mathrm{cm}[1,2]$ for effective ESP performance (fly ash particles are charged and collected with high efficiency). Thus, any resistivity outside this range results in ineffective ESP collection, as the ash may fall in the range of low or high resistivity. Particle collection requires the particles to be charged and retain the charge long enough in order to be repelled by the electric field established in the inter-electrode spacing for collection.

Low resistivity ash, below $1 \times 10^{8} \Omega \cdot \mathrm{cm}$, is difficult

\footnotetext{
Corresponding author: Gerald Chauke, researcher, research field: emissions control. E-mail: Chaukegv@eskom.co.za.
}

to precipitate and collect. The reduced resistivity has been found to be mainly due to the presence of metallic particles and un-burnt carbon in ash. The effect of low resistivity ash during precipitation is that, it easily attains a charge during the ionization process but tends to rapidly lose the charge before collection. The charged particles need to retain a charge long enough to migrate to the collector plate and the loss of charge results particle re-entrainment. Particle re-entrainment occurs when particles re-enter the flue gas stream and are not collected, exiting into the atmosphere. Similar problem exists for high resistivity ash, as particles do not easily attain a charge and thus can not be collected. The problem of high resistivity was solved with flue gas treatment to reduce the resistivity; the most effective and commonly used flue treatment is $\mathrm{SO}_{3}$ injection into the flue gas stream.

The Southern Research Institute [3-6] was at the forefront in conducting research on the measuring of ash resistivity. IEEE Standard 548-1984 was published 
as a guideline on conducting ash resistivity measurements on ash in controlled laboratory environment. Laboratory testing is conducted making use of an ash resistivity test oven. Prior to testing, the ash sample must be analysed for elemental composition, particle size distribution and particle density.

\section{Materials and Methods}

The methodology and materials used in obtained the presented results are discussed in this section.

\subsection{Ash Resistivity Profiling}

The ash resistivity oven is constructed such that it operates in conditions similar to those in fully, operational ESP plants. The oven parameter inputs are moisture, nitrogen, oxygen and temperature conditions in which the ash is exposed too during normal operating conditions.

Figs. 1 and 2 show the experimental set-up that is applied in conducting ash resistivity measurements with connected gas cylinders to be adjusted to model the operating conditions or parameters.

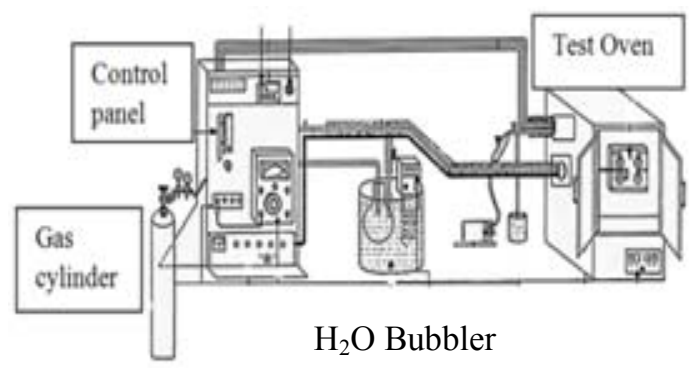

Fig. 1 Fly ash resistivity, test set-up apparatus.

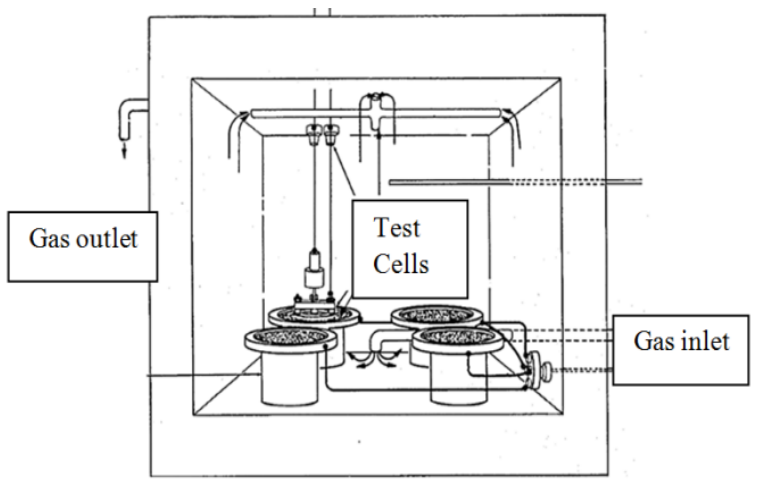

Fig. 2 Resistivity test oven, test electrode arrangement [7].
The measurements are taken for descending temperatures, decrements of $30{ }^{\circ} \mathrm{C}$ from $215{ }^{\circ} \mathrm{C}$ to $95{ }^{\circ} \mathrm{C}$. Current measurements are taken at every temperature set point for an applied voltage. An alternative test procedure with incrementing temperature is as follows [3-6]:

- The collected sample is firstly sieved making use of a $180-\mu \mathrm{m}$ sieve.

- The resistivity-measuring cell is firstly weighed without the ash sample.

- The sieved samples are packed into the resistivity measurement cell and weighed.

Care is taken to insure that the sample is evenly distributed throughout the measurement cell.

The resistivity, measuring cell with the ash sample is placed inside the temperature-controlled chamber.

The voltage lead and the electrometer are connected to the measuring cell; a thermocouple is connected to the measuring cell.

Place the disc electrode on surface of the dust sample.

Set the temperature of the chamber to a temperature $215^{\circ} \mathrm{C}$, the setup is left to run overnight.

A nitrogen flow is introduced during the heating up process, overnight.

The other gases; $\mathrm{CO}_{2}, \mathrm{O}_{2}$ and moisture are introduced into the chamber and allowed to reach equilibrium over a $2 \mathrm{~h}$ period.

Without the voltage supply connected, leakage or induced current is measured from the different cells and recorded.

This leakage current is due to residual charge that is obtained and retain by the ash elements in the heating process.

A voltage supply is introduced to each cell for a period of $60 \mathrm{~s}$ and 12 current measurements are recorded.

The recorded currents are averaged out to get a fair representation of the actual current that flows through the sample.

This procedure is repeated with every temperature decrement. 
The resistivity is determined by solving for Eq. (2); knowing the test electrode's dimensions and dust layer thickness, with the recorded current and voltage values.

Resistivity is defined by the following formulation:

$$
\rho_{R}=\frac{R \cdot A}{l}
$$

Whereby, the ash resistivity $\left(\rho_{R}\right)$ in $\Omega \cdot \mathrm{cm}$ is expressed as a function of the resistance $(R)$, obtained by making use of ohm's law $\left(R=\frac{V}{i}\right), A$ being the area of the collector plate/disc and the dust layer thickness $(l)$. Substituting ohm's law, gives the following expression that can used to determine the ash resistivity:

$$
\rho_{R}=\frac{\Delta V \cdot A}{i \cdot l}
$$

The obtained resistivity results are, plotted as a function of the different temperature set points. An, additional test is conducted whereby for a fixed temperature, the voltage is incremented until spark over occurs, whilst taking current measurements with every voltage increment. The voltage reading recorded before spark over occurs, taken as the electrical breakdown voltage of the dust layer, used in determining the resistivity as a function of varying electric field.

\subsection{High Resistivity Effects on ESP's}

The collected ash, during precipitation accumulates on the grounded collector plate. When, the dust layer builds up on the ESP collector plate, the resistivity also increases. The potential difference between the discharge electrode and collector plate builds up due to the increased resistivity, as leakage current is restricted from flowing to ground. This restriction results in collected charged particle not being able to dissipate their charge through the collector plate and thus leading to a charge build-up on the dust layer. The build up of positive surface charge increases to the point of electrical breakdown, resulting in back-corona. Back-corona is an abnormal gaseous discharge that occurs at the collector electrode and takes place in the presence of corona discharge. The back-corona discharge occurs when the electric field across the dielectric layer is higher than its breakdown strength [7, 8]. Eq. (3) describes the positive electric field that is, created due to charge build-up and acts to reduce the overall negative electric field established by the discharge electrode.

$$
E_{l}=j \rho
$$

This phenomenon is undesired, as the positive corona discharge also results in the collected dust particles being dislodged. The dislodged particles are re-entrained into the flue gas stream. Thus, reduces the collection efficiency of the system.

\section{Results}

In this section, preliminary laboratory experimental results are presented and discussed for ash samples obtained from two power plants.

Ash elementary analysis is conducted on the ash samples. Table 1 lists the elemental composition of the fly ash samples. The elemental composition of the ash is not used in the determination of the resistivity, though it is given that the composition influences the resistivity. No model accurate model is available that correlates the elementary composition to the resistivity for South African coal and ash. The samples have small percentage deviations in their elemental composition.

Test preparations involve the weighing of the ash samples in order to determine the packing density of each cell. Ash samples have different particle size distributions, which influence their respective packing densities. Table 2, represents the masses obtained for samples A and B. The packing densities of the two samples vary slightly, and this is mainly due to the variation in particle size distribution of the samples.

The test oven has been set-up with gas flow inputs and the oven gas composition is determined from plant operating conditions. Table 3 , list the gas compositions and flow set-up for the test oven as determined from plant operating conditions. The gas pressures are, regulated at $400 \mathrm{kPa}$ for the duration of the test. 
Table 1 Fly ash elemental composition.

\begin{tabular}{|c|c|c|}
\hline Elemental composition & Sample A (\%) & Sample B $(\%)$ \\
\hline Silicon $\left(\mathrm{SiO}_{2}\right)$ & 53.4 & 54.8 \\
\hline Aluminium $\left(\mathrm{Al}_{2} \mathrm{O}_{3}\right)$ & 27.5 & 25.4 \\
\hline Iron $\left(\mathrm{Fe}_{2} \mathrm{O}_{3}\right)$ & 3.6 & 3.8 \\
\hline Titanium $\left(\mathrm{TiO}_{2}\right)$ & 1.5 & 1.4 \\
\hline Phosphorous $\left(\mathrm{P}_{2} \mathrm{O}_{5}\right)$ & 0.28 & 0.44 \\
\hline Calcium $(\mathrm{CaO})$ & 6.5 & 7.4 \\
\hline Magnesium (MgO) & 1.3 & 1.5 \\
\hline Sodium $\left(\mathrm{Na}_{2} \mathrm{O}\right)$ & 0.3 & 0.2 \\
\hline Potassium $\left(\mathrm{K}_{2} \mathrm{O}\right)$ & 0.8 & 1.1 \\
\hline Sulphur $\left(\mathrm{SO}_{3}\right)$ & 2.6 & 0.5 \\
\hline
\end{tabular}

Table 2 Test cell dimensions and mass measurements.

\begin{tabular}{|c|c|c|c|c|c|}
\hline \multicolumn{6}{|c|}{ Sample A } \\
\hline Cell \# & $\begin{array}{l}\text { Dia. } \\
(\mathrm{mm})\end{array}$ & $\begin{array}{l}\text { Dish } \\
\text { mass (g) }\end{array}$ & $\begin{array}{l}\text { Dish + dust } \\
\text { mass }(\mathrm{g})\end{array}$ & $\begin{array}{l}\text { Dust } \\
\text { mass (g) }\end{array}$ & $\begin{array}{l}\text { Packing } \\
\text { density }\left(\mathrm{g} / \mathrm{cm}^{3}\right)\end{array}$ \\
\hline 1 & 76.2 & 99.3 & 121.1 & 21.80 & 0.99 \\
\hline 2 & 70 & 116.7 & 135.8 & 19.10 & 1.03 \\
\hline 3 & 70 & 118.8 & 135.8 & 17.00 & 0.89 \\
\hline 4 & 70 & 115.9 & 135.2 & 19.30 & 0.99 \\
\hline \multicolumn{4}{|c|}{ Average } & 19.30 & 0.98 \\
\hline \multicolumn{6}{|c|}{ Sample B } \\
\hline 1 & 76.2 & 99.4 & 111.7 & 12.30 & 0.56 \\
\hline 2 & 70 & 116.9 & 135.4 & 18.50 & 1.00 \\
\hline 3 & 70 & 118.9 & 139.6 & 20.70 & 1.09 \\
\hline 4 & 70 & 116.0 & 122.0 & 18 & 0.93 \\
\hline \multicolumn{4}{|c|}{ Average } & 19.07 & 1.00 \\
\hline
\end{tabular}

Table 3 Gas flows used during testing.

\begin{tabular}{ll}
\hline Gas & Flow $(\mathrm{mL} / \mathrm{min})$ \\
\hline Nitrogen $\left(\mathrm{N}_{2}\right)$ & 8.7 \\
Carbon dioxide $\left(\mathrm{CO}_{2}\right)$ & 13.8 \\
Oxygen $\left(\mathrm{O}_{2}\right)$ & 4.6 \\
\hline
\end{tabular}

The gas flow and temperature conditions were allowed to settle for a period of $24 \mathrm{~h}$ before testing could commence. The obtained results for both samples are as follows.

\subsection{Resistivity Profile at $2 \mathrm{KV}$, Sample A}

The results show the average resistivity of the four test cells tested at $2 \mathrm{kV}$ voltage supply. Fig. 3 graphically illustrates the resistivity profile of sample A. It is noted that at $0 \%$ moisture the resistivity is high, whereas with $7 \%$ moisture, the resistivity is decreased. Moisture provides a surface conduction path for current to flow through, hence the reduction in the

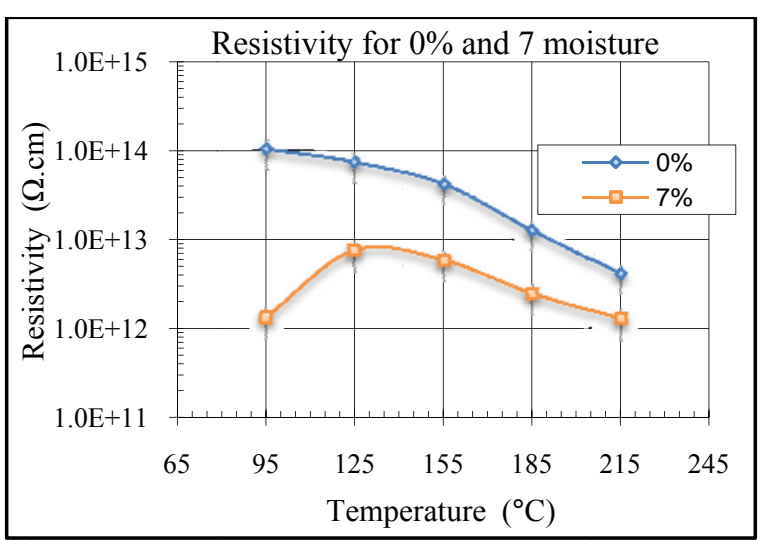

Fig. 3 Resistivity profile at $0 \%$ and $7 \%$ moisture.

sample's resistivity. The lowest resistivity observed at $95{ }^{\circ} \mathrm{C}$ but at $1.28 \mathrm{e}^{12}$ this is deemed to be high resistivity. South African power plant ESP's operates in temperature region of $115{ }^{\circ} \mathrm{C}$ to $150{ }^{\circ} \mathrm{C}$, and based on the results, the resistivity is high at this range of temperatures for sample A.

Table 4 lists the calculated experimental results for sample A. The reduction in resistivity when moisture is introduced into the test oven is most significant at low temperatures and this may be caused by condensation in the system allowing more current to flow through the sample.

\subsection{Resistivity Profile at $2 \mathrm{KV}$, Sample B}

Sample B's resistivity has a similar profile to that of sample $\mathrm{A}$, for $0 \%$ and $7 \%$ moisture (Fig. 4). At $0 \%$ moisture and low temperature the resistivity is at its highest, whereas, with $7 \%$ moisture and low temperature is at its lowest and within the stipulated ESP operating range. This highlights the importance of moisture in an ESP system, for the reduction of the ash resistivity

The calculated experimental results for sample B, are presented in Table 5. The results exhibit a similar pattern to those obtained for sample $\mathrm{A}$, with the highest resistivity reduction observed at lower temperatures.

\subsection{Sample Result Comparison}

The samples had a similar percentage elementary composition and as such, expected to exhibit similar 
Table 4 Samples A experimental results.

\begin{tabular}{lllllll}
\hline $\begin{array}{l}\text { Oven } \\
\text { temperature }\left({ }^{\circ} \mathrm{C}\right)\end{array}$ & 95 & 125 & 155 & 185 & 215 \\
\hline $0 \%$ & $I(\mathrm{~A})$ & $2.01 \mathrm{e}^{-10}$ & $2.85 \mathrm{e}^{-10}$ & $5.17 \mathrm{e}^{-10}$ & $1.69 \mathrm{e}^{-9}$ & $5.31 \mathrm{e}^{-9}$ \\
$\mathrm{H}_{2} \mathrm{O}$ & $\rho_{R}$ & $1.03 \mathrm{e}^{14}$ & $7.31 \mathrm{e}^{13}$ & $4.09 \mathrm{e}^{13}$ & $1.24 \mathrm{e}^{13}$ & $3.96 \mathrm{e}^{12}$ \\
$7 \%$ & $I(\mathrm{~A})$ & $1.62 \mathrm{e}^{-8}$ & $2.82 \mathrm{e}^{-9}$ & $3.63 \mathrm{e}^{-9}$ & $8.59 \mathrm{e}^{-9}$ & $1.66 \mathrm{e}^{-9}$ \\
$\mathrm{H}_{2} \mathrm{O}$ & $\rho_{R}$ & $1.28 \mathrm{e}^{12}$ & $7.34 \mathrm{e}^{12}$ & $5.69 \mathrm{e}^{12}$ & $2.41 \mathrm{e}^{12}$ & $1.24 \mathrm{e}^{12}$ \\
$\rho_{R}$ reduction $(\%)$ & 98.76 & 89.97 & 86.09 & 80.51 & 68.67 \\
\hline
\end{tabular}

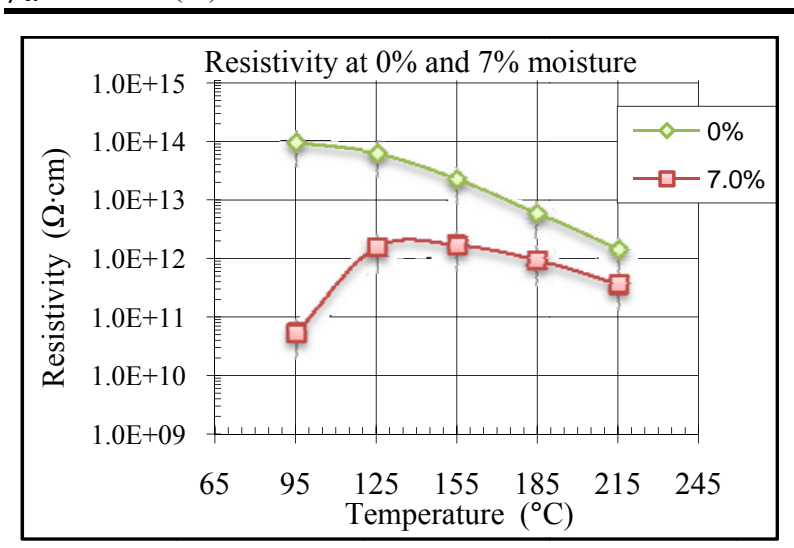

Fig. 4 Sample B, resistivity profile at $0 \%$ and $7 \%$ moisture.

Table 5 Sample B experimental results.

\begin{tabular}{lllllll}
\hline $\begin{array}{l}\text { Oven } \\
\text { temperature }\left({ }^{\circ} \mathrm{C}\right)\end{array}$ & 95 & 125 & 155 & 185 & 215 \\
\hline $0 \%$ & $I(\mathrm{~A})$ & $1.06 \mathrm{e}^{-6}$ & $1.33 \mathrm{e}^{-8}$ & $1.21 \mathrm{e}^{-8}$ & $2.22 \mathrm{e}^{-8}$ & $5.65 \mathrm{e}^{-8}$ \\
$\mathrm{H}_{2} \mathrm{O}$ & $\rho_{R}$ & $9.31 \mathrm{e}^{13}$ & $6.26 \mathrm{e}^{13}$ & $2.26 \mathrm{e}^{13}$ & $5.75 \mathrm{e}^{12}$ & $1.38 \mathrm{e}^{12}$ \\
$7 \%$ & $I(\mathrm{~A})$ & $4.87 \mathrm{e}^{-6}$ & $3.21 \mathrm{e}^{-8}$ & $1.87 \mathrm{e}^{-8}$ & $3.07 \mathrm{e}^{-8}$ & $7.55 \mathrm{e}^{-8}$ \\
$\mathrm{H}_{2} \mathrm{O}$ & $\rho_{R}$ & $5.06 \mathrm{e}^{10}$ & $1.50 \mathrm{e}^{12}$ & $1.63 \mathrm{e}^{12}$ & $8.97 \mathrm{e}^{11}$ & $3.48 \mathrm{e}^{11}$ \\
$\rho_{R}$ reduction $(\%)$ & 99.95 & 97.60 & 92.76 & 84.40 & 74.71 \\
\hline
\end{tabular}

resistivity profile. Fig. 5 illustrates the difference in resistivity profiles for both ash samples.

Sample A has a lower resistivity profile for $0 \%$ moisture at higher temperature as compared to that of sample B. However, sample B appears to have a lower resistivity profile when moisture is introduced into the gas stream. The introduction of moisture, acts to coat the surface of the ash particles and thus reducing the resistivity of the ash samples. The reduction in resistivity means that, in ESP's more ionic current flows and improves the retention of the collected ash. However, the attained resistivity at $7 \%$ moisture may be classified as high resistivity.

The desired resistivity range for efficient ESP operation/collection has been determined to be $1 \times 10^{8}$ to $1 \times 10^{11} \Omega \cdot \mathrm{cm}[1,2]$. The above, obtained results

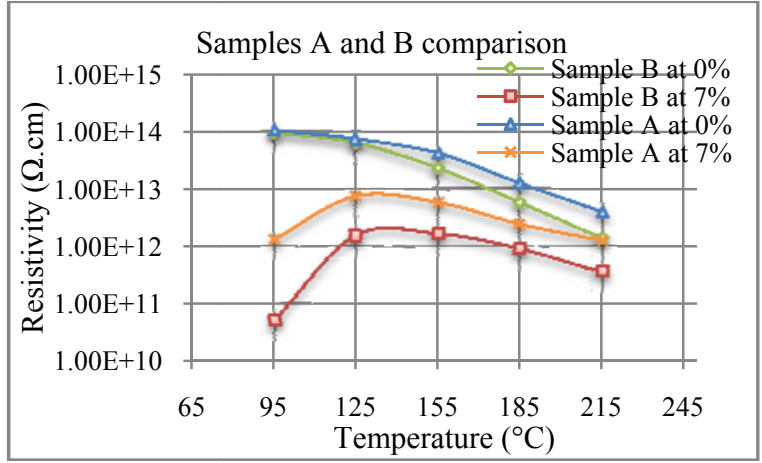

Fig. 5 Samples $A$ and $B$ resistivity profiles.

indicate that South African power plants operate with high ash resistivity, when the ash has only been conditioned by moisture. The desired resistivity is achieved at low temperatures, but ESP's operate at temperatures averaging at $110^{\circ} \mathrm{C}$ to $150^{\circ} \mathrm{C}$.

\section{Conclusions}

The preliminary results of samples A and B, indicates that South African ash has high resistivity for moisture conditioning. The desired resistivity range for efficient ESP operation is $1 \times 10^{8} \Omega \cdot \mathrm{cm}$ to $1 \times 10^{11}$ $\Omega \cdot \mathrm{cm}$. The desired resistivity is achieved at low temperatures, but ESP's operate at temperatures averaging at $110{ }^{\circ} \mathrm{C}$ to $150{ }^{\circ} \mathrm{C}$. The high resistivity results indicate that the ESP's for both sample are operating under back-corona effects. Thus, making it difficult to achieve, the set emissions limit of 75 $\mathrm{mg} / \mathrm{Nm}^{3}$. Due to particle re-entrainment experienced high resistivity ash.

Further studies will be conducted making use of $\mathrm{SO}_{3}$ treatment. The resistivity at $125^{\circ} \mathrm{C}$ and $155^{\circ} \mathrm{C}$ need to be reduced to be below $1 \mathrm{e}^{11} \Omega \cdot \mathrm{cm} . \mathrm{SO}_{3}$ treatment will be investigated to determine whether this can be achieved.

\section{References}

[1] H. White, Industrial Electrostatic Precipitation, Addison-Wesley, London, UK, 1963.

[2] K. Parker, Electrical operation of electrostatic precipitators-IEE power \& energy series, No. 41, London, The Institute of Engineering and technology [Online], 2003, www.epri.com (accessed March 28, 2012).

[3] IEEE Criteria and Guidelines for the Laboratory 
Measurement and Reporting of Fly Ash Resistivity, IEEE Standard 1224/1327/1224.1/1NT, 1994.

[4] G.B. Nicholas, S.M. Banks, Test Methods and Apparatus for Conducting Resistivity Measurement, report No. 3121-III, Alabama, The Southern Research Institute, 1977.

[5] H.W. Spencer, Electrostatic Precipitators: Relationship between Resistivity, Particle Size and Spark-over, report No. EPA-600/2-76-144, Alabama, The Southern Research Institute, 1976.

[6] A. Chandraet, S. Kumar, P.K. Sharma, Investigations on fly ash resistivity: Development of empirical relations based on experimental measurement [Online], Centre for Energy Studies, Indian Institute of Technology Delh., www.isesp.org/ (accessed May 28, 2012).

[7] A. Jaworek, T. Czech, E. Rajch, M. Lackowski, Laboratory studies of back-discharge in fly ash, Journal of Electrostatics [Online]. Published Online: 2006, pp. 326-337, www.elsevier.com/locate/elstat (accessed June 25, 2012).

[8] S. Masuda, A. Mizuno, Basic studies on back discharge mode andstreamer propagation, in: 4th International Clean Air Congress [Online], Tokyo, May 1977, pp. 73-75, www.elsevier.com/locate/elstat (accessed June 18, 2012). 